\title{
PENGARUH KONFLIK KERJA TERHADAP KINERJA PERANGKAT NAGARI DALAM PENGELOLAAN KEUANGAN NAGARI
}

\author{
Virona Endila \\ Jurusan Administrasi Publik, Fakultas Ilmu Sosial, Universitas Negeri Padang \\ dilavirona@gmail.com
}

\begin{abstract}
This study aimed to determine the effect of work conflict on the performance of nagari apparatus in village financial management in several villages (nagari) of Limapuluh Kota District, especially in Situjuah Limo Nagari and Mungka Sub-Districts. This research was conducted because of indications of conflict that occurred in the two Sub-Districts related to nagari financial management. The method used in this study was a quantitative method with associative model. The population in this study were all nagari apparatus in Limapuluh Kota District, totaling 75 respondents. The sample in this study consisted of 63 nagari apparatus determined using the Slovin formula with a 5\% error rate and the use of Multi Stage Random Sampling techniques. Data in this study were collected through questionnaires distributed to respondents with Likert scale measurements. The data are then analyzed using multiple linear regression. The results of the study showed that the effect of the functional sub-variables of work conflict on performance was around 11.5\%; and this functional work conflict has a significant influence on the performance of nagari apparatus in managing nagari finances. While the dysfunctional work conflict subvariables have an influence of 3.5\%; and this dysfunctional work conflicts do not have a significant effect on the performance of nagari apparatus. But overall, work conflict had a significant effect with a value of $17.7 \%$, and this work conflict had a significant influence on the performance of nagari apparatus in managing nagari (village) finance.
\end{abstract}

Keywords: Work conflict, job performance, village financial management

How to Cite: Virona Endila. 2020. Pengaruh Konflik Kerja Terhadap Kinerja Perangkat Nagari dalam Pengelolaan Kuangan Nagari. 4(1): pp. 99-111. DOI: https://doi.org/ 10.24036/jess/vol4-iss1

\section{Pendahuluan}

Dalam Undang-Undang Nomor 6 Tahun 2014 Tentang Desa dinyatakan bahwa Desa atau desa adat atau yang disebut dengan nama lain, selanjutnya disebut Desa adalah kesatuan masyarakat hukum yang memiliki batas wilayah yang berwenang untuk mengatur dan mengurus urusan pemerintahan, kepentingan masyarakat setempat berdasarkan prakarsa masyarakat, hak asal usul, dan/atau hak tradisional yang diakui dan dihormati dalam sistem pemerintahan Negara Kesatuan Republik Indonesia. Desa menurut Widjaja (2010) dalam bukunya yang berjudul "Otonomi Desa" menyatakan bahwa desa merupakan kesatuan masyarakat hukum yang 
mempunyai susunan asli berdasarkan hak asal-usul yang bersifat istimewa. Landasan pemikiran dalam mengenai Pemerintahan Desa adalah keanekaragaman, partisipasi, otonomi asli, demokratisasi dan pemberdayaan masyarakat.

Di Sumatera Barat, istilah Desa diberi nama lain dengan sebutan Nagari, namun banyak hal yang berbeda dari Desa dan Nagari, termasuk dalam pelaksanaan dan struktur pemerintahannya. Dalam Peraturan Daerah Sumatera Barat Nomor 7 Tahun 2018 Tentang Nagari dijelaskan bahwa nagari merupakan kesatuan masyarakat Hukum Adat secara geneologis dan historis, memiliki batas-batas dalam wilayah tertentu, memiliki harta kekayaan sendiri, berwenang memilih pemimpinnya secara musyawarah serta mengatur dan mengurus kepentingan masyarakat setempat berdasarkan filosofi dan sandi adat, "Adat Basandi Syara' Syara' Basandi Kitabullah" dan/atau berdasarkan asal usul dan adat istiadat setempat dalam wilayah Provinsi Sumatera Barat. Sedangkan Pemerintahan Nagari merupakan penyelenggara urusan pemerintahan dan juga kepentingan masyarakat Nagari dalam sistem pemerintahan NKRI. Pemerintahan Nagari menjalankan tugas dan wewenang dalam mengatur Nagari itu sendiri dalam hal struktur pemerintahan dan juga pengelolaan keuangan Nagari.

Pengelolaan Keuangan Desa dinyatakan secara jelas dalam Peraturan Mentri Dalam Negeri nomor 113 tahun 2014, bahwa keuangan desa adalah semua hal dan kewajiban desa yang dapat dinilai dengan uang serta segala sesuatu berupa uang dan barang yang berhubungan dengan pelaksanaan hak dan kewajiban desa. Keuangan desa tersebut harus dikelola berdasarkan asas-asas transparan, akuntabel, partisipatif serta dilakukan dengan tertip dan disiplin anggaran. Pengelolaan keuangan juga membutuhkan sumber daya manusia yang memiliki ketelitian, kerja sama yang tinggi dan rasa tanggung jawab yang tinggiterhadap pekerjaan. Sumber daya manusia merupakan kunci sukses dari suatu organisasi modern. Mengelola sumber daya manusia secara efektif dan mengayomi anggota menjadi tanggung jawab setiap orang dalam suatu perusahaan atau organsasi.

Di Kabupaten Limapuluh Kota, salah satunya di Kecamatan Mungka, konflik kerja juga seringkali terjadi. Konflik kerja yang terjadi di Kecamatan Mungka ini adalah konflik antara perangkat nagari dengan pemerintah pusat serta permasalahan yang terjadi antar karyawan yang memiliki tujuan atau pandangan yang berbeda dalam pengelolaan keuangan nagari. Perbedaan tujuan dan permasalahan sumber daya yang kurang menyebabkan terjadinya konflik yang berpengaruh besar terhadap kinerja perangkat nagari.

Konflik kerja yang dihadapi oleh perangkat nagari di Kecamatan Mungka (berdasarkan wawancara langsung dengan sekretaris nagari di salah satu Kecamatan tersebut, Bapak Syafril, 10 September 2018) adalah adanya kesenjangan dan kesalahpahaman yang terjadi antar perangkat nagari yang membuat kinerja dalam pencapaian tujuan menjadi terganggu. Perangkat nagari dan semua karyawan yang ada di dalam balai nagari memiliki kreatifitas masing-masing untuk menunjang perubahan yang akan dilakukan oleh semua perangkat nagari, namun seringkali inovasi-inovasi tersebut menjadi ajang bagi masing-masing 
perangkat nagari untuk mendapatkan sanjungan dan pujian agar dipandang hebat dalam balai nagari tersebut, bahkan di depan masyarakat setempat. Hal ini terjadi karna persaingan-persaingan kecil yang dapat menimbulkan rasa kepuasan tersendiri di hadapan masyarakat dan pemerintahan pusat yang mengawasi.

Dengan demikian, konflik yang terjadi tersebut dapat memberikan pengaruh yang tidak baik terhadap kinerja perangkat nagari. Konflik lain yang juga sering menjadi permasalahan di dalam perangkat nagari di Kecamatan Mungka ini adalah adanya rasa kurang nyaman saat melakukan kerja kelompok seperti Tim Pengelola Kegiatan (TPK) yang bertugas melaksanakan kegiatan yang telah disepakati saat Musrembang. Kurangnya rasa kekeluargaan dan rasa saling memiliki antar perangkat nagari sehingga dalam pelaksanaan kegiatan apapun mereka hanya terfokus pada tugas masing-masing dan kurang adanya keharmonisan antar perangkat nagari tersebut. Dengan demikian benturan antar kepribadian terjadi dan perselisihan-perselisihan kecil tersebut dikhawatirkan menimbulkan konflik yang besar nantinya.

Hal serupa juga terjadi di kecamatan lain di Kabupaten 50 Kota yaitu kecamatan Situjuah Limo Nagari. Di kecamatan ini konflik kerja juga terjadi di dalam perangkat nagari untuk menjalankan tugasnya. Perselisihan antar karyawan juga terjadi di dalam Kecamatan Situjuah Limo Nagari ini. Bahkan ada perangkat nagari yang sampai sekarang masih berselisih walaupun dalam kinerja masingmasing mereka tetap profesional. Salah satu perangkat nagari, juga sering mendominasi diskusi saat adanya rapat yang dilakukan oleh Perangkat Nagari ini sehingga menimbulkan rasa tidak nyaman oleh perangkat nagari yang lainnya dan tidak senang bekerja dalam kelompok karena kurangnya rasa kebersamaan dalam masing-masing perangkat nagari.

Dari wawancara yang telah dilakukan dengan sekretaris nagari di salah satu Nagari di Kecamatan Situjuah Limo Nagari (Bapak Suryanto, 11 September 2018), konflik kerja yang sebagian besar terjadi disebabkan oleh benturan kepribadian antar masing-masing perangkat nagari. Adanya kepribadian yang berbeda dan susah untuk disatukan dalam sebuah organisasi. Pribadi perangkat nagari yang keras tidak bisa disatukan dengan perangkat nagari yang memiliki kepribadian mudah tersinggung. Dengan demikian, perselisihan sering terjadi dengan adanya perbedaan kepribadian tersebut.

Dalam pengelolaan keuangan nagari, konflik kerja sering kali terjadi karena adanya perbedaan pemahaman dalam menjalankannya. Seperti yang telah dipaparkan di atas, pada umumnya di Kecamatan Mungka pengontrolan dari pusat mengenai pelaksanaan pengelolaan keuangan nagari tidak berjalan dengan baik sehingga kadang-kadang menyebabkan tidak tercapainya tujuan dalam bekerja, termasuk dalam pengelolaan keuangan nagari.

Berdasarkan masalah yang dipaparkan pada latar belakang, penulis tertarik melaksanakan penelitian di Kecamatan Situjuah Limo Nagari dan Kecamatan Mungka. Penelitian ini merupakan intisari dari hasil penelitian skripsi serta merupakan bagian dari penelitian payung dari Syamsir (2017) yang berjudul Model 
Pembinaan Aparatur Pemerintahan Nagari dalam Pengelolaan Keuangan Nagari di Kabupaten Tanah Datar. Rumusan masalah yang diajukan dalam penelitian ini adalah: apakah terdapat pengaruh konflik kerja (yang mencakup dua sub variabel konflik fungsional dan konflik disfungsional) terhadap kinerja perangkat nagari dalam pengelolaan keuangan nagari di Kabupaten Limapuluh Kota, khususnya di Kecamatan Mungka dan Situjuah Limo Nagari?

\section{Tinjauan Kepustakaan}

Kinerja karyawan memiliki pengaruh terhadap produktivitas dari sebuah perusahaan. Apabila kinerja karyawannya buruk maka akan berpengaruh negatif untuk institusi tersebut, tetapi apabila kinerja karyawan baik maka akan berpengaruh positif untuk mewujudkan tujuan institusi tersebut. Perilaku yang nyata yang ditampilkan setiap orang sebagai prestasi kerja yang dihasilkan oleh karyawan sesuai dengan perannya dalam organisasi (Rivai, 2004).

Dalam lingkungan kerja, setiap karyawan dituntut untuk dapat melaksanakan pekerjaan sesuai dengan jabatan yang dipegang, beradaptasi dengan lingkungan, serta menjalin kerjasama dengan rekan kerja yang memiliki karakter berbeda-beda. Interaksi antar individu dan kelompok dalam lingkungan kerja dapat menimbulkan dampak negatif yang memicu terjadinya konflik dan masalah dalam pekerjaan. Konflik di tempat kerja yang berkepanjangan, pemberian beban kerja yang terlalu berlebihan terhadap karyawan antara lain dapat menimbulkan stress kerja yaitu kondisi atau keadaan yang tidak menyenangkan yang dihadapi oleh setiap orang baik secara fisik maupun mental.

Gibson (1985) menyatakan bahwa konflik kerja merupakan pertentangan antara individu, antara kelompok dan antara organisasi yang disebabkan oleh perbedaan komunikasi, tujuan dan sikap. Pendapat senada juga dikemukakan oleh Tommy (2010) bahwa konflik kerja adalah pertentangan antara seseorang dengan orang lain atau ketidakcocokan kondisi yang dirasakan oleh pegawai karena adanya hambatan komunikasi, perbedaan tujuan dan sikap serta tergantungan aktivitas kerja. Selanjutnya, menurut Mangkunegara (2009) konflik kerja adalah suatu situasi dimana terjadi adanya pertentangan antara dua atau lebih anggota organisasi atau kelompok-kelompok dalam organisasi yang timbul karena adanya kegiatan bersama-sama yang mempunyai perbedaan status, tujuan, nilai-nilai, dan persepsi yang berbeda.

Pada hakekatnya konflik tidak bisa dihindari tetapi bisa diminimalkan agar konflik tidak mengarah perpecahan, permusuhan bahkan mengakibatkan suatu organisasi mengalami kerugian. Tetapi, jika konflik dapat diolah dengan baik maka suatu organisasi memperoleh keuntungan yang maksimal seperti menciptakan persaingan yang sehat antar pegawai atau karyawan. Jadi, pihak manajemen atau pimpinan dapat menangkap gejala-gejala dan indikator-indikator konflik yang berdampak konstruktif dan konflik yang berdampak destruktif. Pihak manajemen 
harus benar-benar jeli dalam melihat, memperhatikan dan merasakan perilakuperilaku karyawannya agar konflik yang negatif dapat ditekan.

Konflik bisa menimbulkan dampak negatif misalnya, melemahnya hubungan antar pribadi, timbulnya sikap marah, perasaan terluka, keterasingan. Akibat dari itu semua aktivitas produksi dapat terganggu karena akan terjadi pemborosan waktu dan energi untuk menenangkan, individu-individu yang terlibat akan mengalami stres yang dapat mengurangi kinerjanya. Akan tetapi, tidak hanya itu saja akibat yang ditimbulkan oleh konflik yang tidak ditangani secara cermat dan tepat, dapat pula berakibat langsung pada diri karyawan, karena mereka berada dalam suasana serba salah, sehingga mengalami tekanan jiwa.

Dalam masalah pengelolaan keuangan nagari, konflik antar perangkat nagari sering ditemui. Masalah komunikasi atau tekanan kerja yang begitu berat untuk diselesaikan tentu sangat menganggu kinerja karyawan itu sendiri. Bahkan dalam keuangan nagari sekalipun, konflik kerja sangat sering terjadi antara karyawan dengan pemerintah pusat maupun karyawan dengan masyarakat serta tak menutup kemungkinan konflik yang terjadi antar karyawan itu sendiri yang sangat memberikan pengaruh besar terhadap kinerja karyawan atau pegawai.

Untuk mendukung penelitian yang dilakukan peneliti maka diperlukan penelitian yang serupa yang telah dilakukan sebelumnya. Agar dapat dilihat dan diketahui apakah penelitian ini berpengaruh dan mendukung penelitian sebelumnya. Berikut peneliti kemukakan beberapa penelitian yang terkait dengan penelitian ini:

1. Ahiruddin (2011) pernah melakukan penelitian tentang Pengaruh Konflik dan Stres terhadap Kinerja Karyawan CV. Bina Cipta Nusa Perkasa Bandar Lampung. Dari hasil penelitiannya tersebut ia menemukan bahwa konflik dan stres memiliki hubungan positif dengan kinerja pegawai.

2. Bernard E.Silaban (2012) juga pernah melakukan penelitian tentang Pengaruh Konflik terhadap Kinerja Karyawan. Dengan analisis deskriptif dan asosiatif ia menemukan tidak adanya pengaruh antara konflik yang dilihat dari sumber konflik yaitu komunikasi terhadap kinerja karyawan, meskupun pendapat lainnya menyimpulkan bahwa ada pengaruh konflik yang dilihat dari sumber konflik yaitu komunikasi terhadap kinerja karyawan.

3. Dini Kurniasari (2013) juga pernah melakukan penelitian tentang Pengaruh Konflik Peran dan Stres Kerja Terhadap Kinerja Karyawan PT. Glory Industrial Semarang II. Melalui analisis jalur ia menemukan bahwa konflik memiliki pengaruh negatif dan signifikan terhadap kinerja karyawan.

Memang banyak variabel dan/atau faktor yang berpengaruh terhadap pengelolaan keuangan nagari, seperti kompetensi aparatur, kepuasan kerja, motivasi kerja (Syamsir, 2020; Baiyulis, Syamsir, dan Jumiati, 2018; Novia, 2017; Rozanti, 2017), lingkungan kerja (Jayanti dan Syamsir, 2018), kompensasi (Rahmi Suci dan Syamsir, 2018), pengalaman kerja (Fatmaliza, Syamsir, dan Jumiati, 2018); namun faktor atau variabel konflik kerja merupakan salah satu variabel yang 
perlu pula dipertimbangkan dan diwaspadai dalam mempengaruhi kinerja pengelolaan keuangan nagari.

\section{Metode Penelitian}

Metode penelitian yang digunakan dalam penelitian ini adalah metode penelitian kuantitatif. Populasi dalam penelitian ini adalah seluruh perangkat nagari yang ada pada seluruh nagari di Kecamatan Situjuah Limo Nagari dan Kecamatan Mungka sebanyak 75 orang. Dengan menggunakan rumus Slovin diperoleh sampel yang digunakan sebanyak 63 responden dan teknik yang digunkan adalah teknik proportionate stratified random sampling.

Data dalam penelitian ini dikumpulkan melalui penyebaran angket kepada responden dengan 4 opsi jawaban berdasarkan pengukuran menggunakan skala Likert yang terdiri dari (sangat setuju, setuju, kurang setuju, dan tidak setuju). Kemudian analisis data dilakukan dengan teknik regresi linear berganda. Sebelum uji regresi perlu dilakukannya uji asumsi klasik sebagai persyaratan dalam uji regresi. Selain itu untuk mendapatkan gambaran umum tentang kedua variable juga digunakan frekuensi, mean, dan TCR (Tingkat Capaian Responden).

\section{Hasil Penelitian dan Pembahasan}

Sesuai dengan uraian yang dikemukakan dalam pendahuluan, terkait pertanyaan penelitian atau rumusan masalah maka pada bagian ini akan dikemukakan hasil penelitian dan pembahasannya. Sesuai rumusan masalah penelitian mengenai apakah terdapat pengaruh konflik kerja terkait konflik fungsional yang bersifat mendorong perubahan dan konflik disfungsional yang menghambat perubahan terhadap kinerja perangkat nagari dalam pengelolaan keuangan nagari di Kabupaten 50 Kota, maka untuk menjawab pertanyaan tersebut dapat dilihat hasil analisis data penelitian seperti disajikan pada beberapa tabel berikut.

Tabel 1. Pengaruh sub variabel konflik kerja fungsional terhadap kinerja perangkat nagari

Model Summary ${ }^{b}$

\begin{tabular}{lccccc}
\hline Model & R & R Square & $\begin{array}{c}\text { Adjusted R } \\
\text { Square }\end{array}$ & $\begin{array}{c}\text { Std. Error of } \\
\text { the Estimate }\end{array}$ & $\begin{array}{c}\text { Durbin- } \\
\text { Watson }\end{array}$ \\
\hline 1 & $.359^{\text {a }}$ & .129 & .115 & .319 & 1.911 \\
\hline a. Predictors: (Constant), Rata-rata Fungsional & & & \\
b. Dependent Variable: Rata-Rata Pengelolaan Keuangan &
\end{tabular}


Tabel 2. Hasil Uji Anova (F) pengaruh sub variable konflik kerja fungsional terhadap kinerja perangkat nagari

\begin{tabular}{lccccc}
\multicolumn{6}{c}{ ANOVA $^{\mathbf{b}}$} \\
\hline Model & Sum of Squares & Df & Mean Square & F & Sig. \\
\hline Regression & .964 & 1 & .964 & 9.467 & $.003^{\text {a }}$ \\
Residual & 6.516 & 64 & .102 & & \\
Total & 7.480 & 65 & & & \\
\hline
\end{tabular}

a. Predictors: (Constant), Rata-rata Fungsional

b. Dependent Variable: Rata-Rata Pengelolaan Keuangan

Pada Tabel 1 terlihat bahwa nilai Adjusted $R$ Square yang diperoleh dari analisis regresi adalah sebesar 0.115 . Artinya, secara parsial besarnya pengaruh variabel konflik kerja fungsional terhadap kinerja perangkat nagari dalam pengelolaan keuangan nagari adalah sebesar 11,5\%. Selain itu, bila diperhatikan hasil Uji Anova pada Tabel 2 di atas dapat pula dilihat bahwa hasil atau angka signifikansi pengaruh menunjukkan angka $0,003^{\mathrm{a}}$. Artinya, kebenaran kesimpulan hasil uji regresi ini dapat dipercaya sampai $99,99 \%$ atau hampir $100 \%$.

Selanjutnya, hasil analisis tentang pengaruh konflik kerja disfungsional yang menghambat perubahan dapat dilihat dari beberapa tabel berikut ini.

Tabel 3. Pengaruh sub variabel konflik kerja disfungsional terhadap kinerja perangkat nagari

Model Summary ${ }^{\mathrm{b}}$

\begin{tabular}{cccccc}
\hline Model & R & R Square & $\begin{array}{c}\text { Adjusted R } \\
\text { Square }\end{array}$ & $\begin{array}{c}\text { Std. Error of } \\
\text { the Estimate }\end{array}$ & $\begin{array}{c}\text { Durbin- } \\
\text { Watson }\end{array}$ \\
\hline 1 & $.224^{\mathrm{a}}$ & .050 & .035 & .333 & 1.488 \\
\hline
\end{tabular}

a. Predictors: (Constant), Rata-rata Disfungsional

b. Dependent Variable: Rata-Rata Pengelolaan Keuangan 
Tabel 4. Hasil Uji Anova (F) pengaruh sub variable konflik kerja disfungsional terhadap kinerja perangkat nagari

\begin{tabular}{lrrrrr}
\multicolumn{7}{c}{ ANOVA $^{\mathbf{b}}$} \\
\multicolumn{1}{c}{ Model } & \multicolumn{1}{c}{ Sum of } & \multicolumn{1}{c}{} & \\
\hline Squares & Df & Mean Square & \multicolumn{1}{c}{ F } & \multicolumn{1}{c}{ Sig. } \\
\hline Regression & .375 & 1 & .375 & 3.378 & $.071^{\text {a }}$ \\
Residual & 7.105 & 64 & .111 & & \\
Total & 7.480 & 65 & & & \\
\hline
\end{tabular}

a. Predictors: (Constant), Rata-rata Disfungsional

b. Dependent Variable: Rata-Rata Pengelolaan Keuangan

Pada Tabel 3 nilai Adjusted $R$ Square yang diperoleh dari analisis regresi adalah sebesar 0,35 . Artinya, secara parsial besarnya pengaruh variabel konflik kerja disfungsional terhadap kinerja perangkat nagari dalam pengelolaan keuangan nagari adalah sebesar 3,5\%. Selain itu, bila diperhatikan hasil Uji Anova pada Tabel 4 di atas dapat pula dilihat bahwa hasil atau angka signifikansi pengaruh menunjukkan angka $0,071^{\mathrm{a}}$. sehingga dapat disimpulkan bahwa konflik kerja disfungsional tidak memberikan kontribusi atau pengaruh signifikan terhadap kinerja perangkat nagari dalam pengelolaan keuangan nagari di Kabupaten 50 Kota.

Selanjutnya, secara simultan atau secara keseluruhan, pengaruh konflik kerja, yang mencakup konflik fungsional dan konflik disfungsional, dapat pula dilihat pada tabel-tabel berikut ini.

Tabel 5. Hasil Uji Autokorelasi Pengaruh Konflik Kerja terhadap Kinerja Perangkat Nagari dalam Pengelolaan Keuangan Nagari

Model Summary ${ }^{b}$

\begin{tabular}{cccccc}
\hline Model & R & R Square & $\begin{array}{c}\text { Adjusted R } \\
\text { Square }\end{array}$ & $\begin{array}{c}\text { Std. Error of } \\
\text { the Estimate }\end{array}$ & $\begin{array}{c}\text { Durbin- } \\
\text { Watson }\end{array}$ \\
\hline 1 & $.450^{\mathrm{a}}$ & .202 & .177 & .308 & 1.976 \\
\hline
\end{tabular}

a. Predictors: (Constant), Rata-rata Fungsional, Rata-rata Disfungsional

b. Dependent Variable: Rata-Rata Pengelolaan Keuangan 


\section{Tabel 6 Hasil Uji Anova (F) Variabel Konflik Kerja terhadap Pengelolaan Keuangan Nagari}

\section{ANOVA $^{b}$}

\begin{tabular}{lccccc}
\hline \multicolumn{1}{c}{ Model } & $\begin{array}{c}\text { Sum of } \\
\text { Squares }\end{array}$ & Df & Mean Square & F & Sig. \\
\hline Regression & 1.514 & 2 & .757 & 7.994 & $.001^{\text {a }}$ \\
Residual & 5.966 & 63 & .095 & & \\
Total & 7.480 & 65 & & & \\
\hline
\end{tabular}

a. Predictors: (Constant), Rata-rata Fungsional, Rata-rata Disfungsional

b. Dependent Variable: Rata-Rata Pengelolaan Keuangan

Berdasarkan tebel 5 di atas dapat di pahami bahwa, nilai Adjusted R Square adalah sebesar 0,177. Artinya pengaruh konflik kerja terhadap pengelolaan keuangan nagari sebesar $17,7 \%$. Sisanya sebesar $79,3 \%$ dipengaruhi oleh variabel lain yang tidak diteliti dalam penelitian ini. Berdasarkan tabel 6 nilai signifikansi sebesar 0.001. Karena signifikansi uji nilainya lebih kecil dari 0,05 maka dapat disimpulkan bahwa variabel konflik kerja berpengaruh terhadap pengelolaan keuangan nagari, dan hal ini berarti bahwa Ho ditolak dan Ha diterima. Dengan demikian dapat disimpulkan bahwa besarnya pengaruh variabel konflik kerja terhadap kinerja perangkat nagari dalam pengelolan keuangan nagari sebesar $17.7 \%$ bisa dipercaya $100 \%$ dan dapat dipakai untuk memprediksi kinerja perangkat nagari dalam pengelolan keuangan nagari.

Hasil penelitian mengenai pengaruh konflik kerja terhadap kinerja perangkat nagari dalam pengelolaan keuangan nagari di Kecamatan Situjuah Limo Nagari dan Kecamatan Mungka membuktikan bahwa konflik kerja berpengaruh terhadap kinerja perangkat nagari dalam pengelolaan keuangan nagari secara simultan. Pengaruh konflik kerja terhadap kinerja perangkat nagari dalam pengelolaan keuangan nagari di Kecamatan Situjuah Limo Nagari dan Kecamatan Mungka menghasilkan angka signifikansi 0,001 dan nilai Adjust $R$ Square sebesar 0,177 sehingga dapat dikatakan bahwa kontribusinya adalah sebesar 17,7\%. Dari penjelasan di atas dapat ditarik kesimpulan bahwa konflik kerja kerja memiliki pengaruh secara signifikan terhadap kinerja perangkat nagari dalam pengelolaan keuangan nagari di Kecamatan Situjuah Limo Nagari dan Kecamatan Mungka.

Dari hasil yang dijabarkan tersebut dapat dikemukaan hasil bahwa di Kabupaten 50 Kota khususnya di Kecamatan Situjuah Limo Nagari dan Kecamatan Mungka, konflik kerja dapat mempengaruhi kinerja perangkat nagari sehingga menyebabkan terhambatnya tujuan dalam bekerja. Sedangkan secara per sub variabel, tidak kedua sub variabel yyang memberikan pengaruh terhadap kinerja 
perangkat negara. Konflik kerja disfungsional yang dapat menghambat perubahan tidak memberikan kontribusi yang banyak terhadap kinerja pegawai, hanya memberikan kontrubusi sebesar 3,5\%; sehingga dapat ditarik kesimpulan bahwa di Kabupaten Limapuluh Kota, konflik kerja yang memberikan pengaruh terhadap kinerja adalah konflik kerja fungsional yang dapat mendorong perubahan. Namun secara keseluruhan, konflik kerja pada dua kecamatan di Kabupaten Limapuluh Kota memberikan pengaruh terhadap kinerja perangkat nagari dalam pengelolaan keuangan.

Hasil penelitian ini memperkuat teori-teori yang telah dijelaskan pada bagian kajian teori bahwa konflik kerja berpengaruh terhadap kinerja. Begitu juga asumsi dari teori konflik pada umumnya yang didapatkan dari para teoretisi konflik juga terindikasi bahwa konflik kerja dapat berpengaruh positif untuk memperkuat hubungan antara rekan kerja atau sering disebut dengan konflik fungsional. Konflik kerja di Kabupaten Limapuluh Kota memberikan pengaruh yang signifikan terhadap kinerja perangkat nagari khusunya perangkat nagari di Kecamatan Situjuah Limo Nagari dan Kecamatan Mungka. Hasil penelitian ini sejalan dengan penelitian yang telah dilakukan oleh Dini Kurniasari (2013) dengan judul pengaruh konflik peran dan stres kerja terhadap kinerja karyawan PT. Glory Industrial Semarang II. Melalui analisis jalur ia menemukan bahwa konflik memiliki pengaruh negatif dan signifikan terhadap kinerja karyawan. Ini membuktikan bahwa konflik dalam dunia kerja memang memiliki pengaruh yang cukup besar kepada pegawai ataupun perangkat nagari. Tidak hanya berpengaruh negatif, konflik juga memberikan pengaruh positif terhadap kinerja perangkat nagari. Konflik yang bersifat positif ini mampu mendorong semua perangkat nagari di Kecamatan Situjuah Limo Nagari dan Kecamatan Mungka mendapatkan dorongan untuk melakukan perubahan.

Konflik di dunia kerja khususnya di Kecamatan Mungka dan Kecamatan Situjuah Limo Nagari memiliki pengaruh yang cukup besar terhadap kinerja masing-masing perangkat nagari khusunya dalam bidang pengelolaan keuangan nagari. Banyaknya konflik yang terjadi mampu membuat semua perangkat nagari menjadi berlomba-lomba melakukan pekerjaan dengan baik. Namun, hal negatif yang ditimbulkan dari adanya konflik ini yaitu tidak adanya keharmonisan yang terjadi di dalam balai nagari khususnya yang memiliki konflik satu sama lain. Dengan demikian, konflik memiliki peranan yang penting terhadap kinerja masingmasing perangkat nagari sesuai dengan hasil penelitian yang telah dilakukan.

Secara teori, penelitian ini mendukung pendapat ahli Anwari (2016) yang menyatakan bahwa konflik kerja sangat berpengaruh penting terhadap kinerja karyawan maupun pegawai. Dengan adanya konflik dapat menghambat perubahan maupun dapat mendorong perubahan itu sendiri tergantung pada cara manajer mengelola konflik menjadi sesuatu yang menguntungkan bagi perusahaan. Lain halnya dengan yang dipaparkan oleh Julvia, dkk. (2016) menyatakan bahwa konflik kerja secara signifikan berpengaruh positif terhadap kinerja karyawan sehingga konflik kerja harus lebih dikelola sehingga konflik dapat melaju kineja karyawan 
dengan baik. Banyak dari penelitian terdahulu yang menyatakan bahwa tak jarang konflik berpengaruh positif terhadap kinerja yang membuat semua karyawan merasa lebih tertantang dan semangat dengan adanya rasa ingin lebih baik dari rekan kerja yang berkonflik dengannya. Hal ini menjadi bukti bahwa konflik tidak hanya memberikan pengaruh negatif namun juga memberikan pengaruh yang positif terhadap kinerja karyawan.

Hasil penelitian ini juga didukung oleh penelitian terdahulu oleh Ahmad Yofandi (2017), yang menyatakan bahwa konflik berpengaruh terhadap kinerja pegawai. Hal ini dilihat dari hasil pencapaian dari olahan angket tidak sesuai dengan standar tinggi yang diharapkan sehingga ditarik kesimpulan bahwa semakin tinggi konflik kerja, maka kinerja karyawan akan semakin rendah. Dengan demikian konflik negatif sangat mempengaruhi kinerja karyawan khususnya kinerja yang seharusnya dikerjakan secara bersama-sama.

Dari penjabaran diatas, dapat ditarik kesimpulan dalam penelitian ini bahwa di Kabupaten 50 Kota khususnya di Kecamatan Situjuah Limo Nagari dan Kecamatan Mungka, konflik kerja memberikan pengaruh yang cukup besar sehingga menurunnya kinerja karyawan terutama dalam pengelolaan keuangan nagari. Semakin besar konflik yang terjadi, maka kinerja karyawan akan semakin menurun. Sehingga dengan demikian dalam hal ini dibutuhkan manajamen konflik yang baik oleh perangkat yang memiliki sifat netral dan bisa meredakan konflik yang ada di dalam dunia kerja khusunya bagi perangkat nagari yang memiliki konflik kerja.

\section{Penutup}

Berdasarkan hasil temuan dan pembahasan yang telah dijelaskan sebelumnya, maka dapat penulis ambil simpulkan bahwa:

1. Pengaruh konflik kerja fungsional (X1) terhadap pengelolaan keuangan nagari memiliki nilai Adjust $R$ Square 0,115, yang artinya pengaruh variabel fungsional terhadap pengelolaan keuangan nagari ada sebesar 11,5\%. Dalam hal ini konflik kerja fungsional memiliki pengaruh signifikan terhadap kinerja dalam pengelolaan keuangan nagari. Secara parsial nilai signifikansi variabel lebih kecil dari 0,05, maka Ho di tolak dan Ha diterima.

2. Pengaruh konflik kerja disfungsional (X2) terhadap pengelolaan keuangan nagari memiliki nilai Adjust $R$ Square 0,035, yang artinya pengaruh variabel disfungsional terhadap pengelolaan keuangan nigari ada sebesar 3,5\%. Dalam hal ini konflik kerja disfungsional tidak memiliki pengaruh signifikan terhadap kinerja dalam pengelolaan keuangan nagari. Secara parsial nilai signifikansi variabel lebih besar dari 0,05, maka Ho di terima dan Ha ditolak.

3. Pengaruh konflik kerja (X) terhadap pengelolaan keuangan nagari (Y) memiliki nilai Adjust $R$ Square 0,177, yang artinya pengaruh konflik kerja terhadap pengelolaan keuangan nagari sebesar $17,7 \%$. Dalam hal ini konflik kerja memiliki pengaruh signifikan terhadap kinerja dalam pengelolaan keuangan 
nagari. Secara parsial nilai signifikansi variabel lebih kecil dari 0.05, maka Ho di tolak dan Ha diterima.

\section{DAFTAR KEPUSTAKAAN}

\section{Buku, Jurnal, Karya Ilmiah Lainnya}

Ahiruddin. (2011). Pengaruh Konflik dan Stress Terhadap Kinerja Karyawan CV. Bina Cipta Nusa Perkasa Bandar Lampung. JurnalOrganisasi dan Manajemen, Vol. I, No:1 (82-88) Oktober 2011.

Anwari, Muhamad Rosidhan, Bambang Swasto Sunuharyo, dan Ika Ruhana. (2016). Pengaruh Konflik Kerja dan Stres Kerja Terhadap Kinerja Karyawan (Studi Pada Karyawan PT. Telkomsel Branch Malang). Jurnal Administrasi Bisnis (JAB), Vol. 41 No.1 Desember 2016.

Baiyulis, B., Syamsir, S., dan Jumiati, J. (2018). Pengaruh Kepuasan Kerja Terhadap Kinerja Perangkat Nagari dalam Pengelolaan Keuangan Nagari di Kecamatan Sungai Tarab dan Salimpaung. Journal of Education on Social Science. Vol. 1(1): pp. 73-84. DOI: https://doi.org/10.24036/jess/vol2-iss2.

Kurniasari, Dini. (2013). Pengaruh Konflik Peran dan Stres Kerja Terhadap Kinerja Karyawan PT. Glory Industrial Semarang II. Skripsi, Fakultas Ekonomi \& Bisnis, Universitas Dian Nuswantoro, Semarang.

Fatmaliza, F., Syamsir, S., dan Jumiati, J. (2018). Kontribusi Pengalaman Kerja Terhadap Kinerja Perangkat Nagari dalam Pengelolaan Keuangan Nagari di Kabupaten Tanah Datar. Journal of Education on Social Science. Vol. 1(1): pp. 85-98. DOI: https://doi.org/10.24036/jess/vol2-iss2

Gibson, J.L. dkk. (1985). Organisasi: Perilaku, Struktur, Proses. Edisi 5, Jilid 1. Jakarta: Erlangga.

Jayanti, Nur Putri dan Syamsir, S. (2018). Pengaruh Lingkungan Kerja Terhadap Kinerja Perangkat Nagari dalam Pengelolaan Keuangan Nagari di Kabupaten Tanah Datar. Journal of Education on Social Science. Vol. 2(1): pp. 35-46, DOI: https://doi.org/10.24036/jess/vol2-iss1

Julvia, Cristine. (2016). Pengaruh Stres Kerja dan Konflik Kerja Terhadap Kinerja Karyawan. Jurnal Ilmiah Manajemen Bisnis, Vol. 16, No. 1, Januari - Juni 2016.

Mangkunegara, A.A. Anwar Prabu. (2009). Manajemen Sumber Daya Manusia Perusahaan. Bandung: Remaja Rosda Karya.

Suci, Rahmi dan Syamsir, S. (2018). Pengaruh Kompensasi Terhadap Kinerja Perangkat Nagari dalam Pengelolaan Keuangan Nagari di Kabupaten Tanah 
Datar. Journal of Education on Social Science. Vol. 2(1): pp. 47-58, DOI: https://doi.org/10.24036/jess/vol2-iss1

Ratu Novia. (2017). Pengaruh Motivasi Kerja Terhadap Kinerja Perangkat Nagari dalam Pengelolaan Keuangan Nagari di Kabupaten Tanah Datar. Journal of Education on Social Science. Vol. 1(2): pp. 120-131, DOI: https://doi.org/10.24036/jess/vol1-iss2

Rivai, Veitzhal. (2004). Manajemen Sumber Daya Manusia Untuk Perusahaan Dari Teori ke Praktik. Jakarta: PT. Rajagrafindo Persada.

Silaban, Bernard E. dan Novrisca. (2012). Pengaruh Konflik Terhadap Kinerja Karyawan (Studi Kasus pada PT. RSP). Jurnal ESENSI. Volume 15 No.1/April 2012. Institut Bisnis Nusantara, Jakarta.

Syamsir, S. (2017). Model Pembinaan Kapasitas Aparatur Pemerintahan Nagari dalam Pengelolaan Keuangan Nagari di Kabupaten Tanah Datar Provinsi Sumatera Barat. Laporan Penelitian (Research Report) https://osf.io/preprints/inarxiv/f7khw

Syamsir, S. (2020). Competence, Job Satisfaction, Work Motivation, and Job Performance of the Village ("Nagari") Masters in Managing E-Village Finance. International Journal of Advanced Science and Technology, 29(08), 1337-1350. Retrieved from http://sersc.org/journals/index.php/IJAST/article/view/20153; and http://repository.unp.ac.id/id/eprint/26930

Tania Rozanti. (2017). Pengaruh Kompetensi Terhadap Kinerja Perangkat Nagari dalam Pengelolaan Keuangan Nagari di Kabupaten Tanah Datar. Journal of Education on Social Science. Vol. 1(2): pp. 132-142, DOI: https://doi.org/10.24036/jess/vol1-iss2

Tommy, Y.D. (2010). Pengaruh Konflik Kerja terhadap Burnout pada Pegawai Bagian Produksi UD. Abadi Lestari Bojonegoro. Skripsi. Malang: Universitas Negeri Malang.

Wijaya, HAW. (2010). Otonomi Desa. Jakarta: PT. RajaGrafindo Persada.

\section{Peraturan Perundang-undangan}

Peraturan Daerah Provinsi Sumatera Barat No 7 Tahun 2018 Tentang Nagari.

Undang-Undang Nomor 6 Tahun 2014 Tentang Desa

Peraturan Menetri Dalam Negeri Nomor 113 tahun 2014 tentang Pengelolaan Keuangan Desa.

Peraturan Pemerintah Nomor 47 Tahun 2015 tentang Peraturan Pelaksanaan Undang-Undang Nomor 6 Tahun 2014 tentang Desa 